\title{
HISTOPATHOLOGICAL ANALYSIS OF BASAL CELL CARCINOMA
}

\author{
Divya Poosarla1, Sabbavarapu Mary Lavanya², Epari Kiran Kumar ${ }^{3}$
}

${ }^{1}$ Assistant Professor, Department of Pathology, Maharajah's Institute of Medical Sciences (MIMS), Vizianagaram, Andhra Pradesh, India.

23rd Year Postgraduate Student, Department of Pathology, Maharajah's Institute of Medical Sciences (MIMS), Vizianagaram, Andhra

Pradesh, India.

${ }^{3}$ Professor and HOD, Department of Pathology, Maharajah's Institute of Medical Sciences (MIMS), Vizianagaram, Andhra Pradesh, India.

\section{BACKGROUND}

ABSTRACT

In the present scenario, Basal Cell Carcinoma (BCC) is the most common cutaneous malignant tumour. In Indian literature, the incidence of BCC ranges from $12 \%$ to $30 \%$. BCC is mostly seen on hair-bearing areas of skin, especially on the face. They have predilection for sun exposed skin (face, hands), most frequently on the lower eyelid and medial canthus in elderly patients.

Aim: To study the histomorphological features of BCC.

\section{MATERIALS AND METHODS}

This is a descriptive study of 30 cases of histopathologically confirmed BCC from January 2016 to December 2017 in the Department of Pathology, Maharajah's Institute of Medical Sciences, Vizianagaram. Patients with suspected lesions were screened for BCC and a detailed history along with examination, laboratory and radiological investigations were conducted. After gross examination, findings were recorded and sections from representative areas were taken and subjected to processing by routine histopathological techniques.

\section{RESULTS}

A total of 30 patients were studied in the study, out of which 14 (46.67\%) were males and 16 (53.33\%) were females. The mean age of the sample patients was 60 years. $90 \%$ of cases were located on the head and neck region, the most common site being lower eyelids. On histological examination the commonest type was solid or nodular with peripheral palisading (56.67\%), the second commonest was pigmented (16.67\%) followed by keratotic (Basosquamous) type (10\%) and adenoid (6.67\%). Cystic type and infiltrating were the least common.

\section{CONCLUSION}

Any fungating mass over the sun exposed areas particularly face, BCC is taken into consideration as it can be easily diagnosed by histopathology.

\section{KEY WORDS}

Basal Cell Carcinoma, Histopathology, Location.

HOW TO CITE THIS ARTICLE: Poosarla D, Lavanya SM, Kumar EK. Histopathological analysis of basal cell carcinoma. J. Evolution Med. Dent. Sci. 2018;7(31):3509-3512, DOI: 10.14260/jemds/2018/789

\section{BACKGROUND}

In the present scenario, Basal Cell Carcinoma (BCC) is being the most common cutaneous malignant tumour. Basal Cell Carcinoma (BCC) was first described by Jacob in the year 1827. Its name is taken from the basal cell layer, as the tumour cells resemble the basal cell layer of the epidermis. ${ }^{1}$ In Indian literature, the incidence of BCC ranges from $12 \%$ to $30 \%$. BCC is mostly seen on hair bearing areas of skin, especially on the face. ${ }^{2}$ Over the face, the lower eyelid is most commonly involved. Exposure to sunlight is one of the most important risk factors. ${ }^{3}$ Sunlight is the most frequent association with development of BCC. Risk correlates with the amount and nature of accumulated exposure, especially during childhood. Prolonged exposure of ultraviolet light is one of the most important predisposing factors. 4

'Financial or Other Competing Interest': None.

Submission 24-04-2018, Peer Review 15-07-2018,

Acceptance 21-07-2018, Published 30-07-2018.

Corresponding Author:

Sabbavarapu Mary Lavanya,

\#34-14-71, Manual Street,

Gnanapuram, Visakhapatnam-530004,

Andhra Pradesh, India.

E-mail: mary.lavanya@gmail.com

DOI: $10.14260 /$ jemds $/ 2018 / 789$
Other predisposing factors are radiotherapy exposure, arsenic, albinism, burns, scars, immunosuppression and Gorlin syndrome. Sun exposed areas of skin (Face and hands) show small, well-circumscribed, pearly tan-grey papule devoid of scaly lesions enlarge with time and tend to ulcerate. These ulcers are called as rodent ulcers. It is a locally destructive tumour with vast variety of clinical and histological appearances. Patients with xeroderma pigmentosum, who have a diminished capability for repairing sun-induced mutations, develop a large number of basal cell and squamous cell carcinomas (SCCs) early in life.

Multiple BCCs develop early in life in patients with basalcell nevus syndrome or Bazex syndrome. Clinical appearance often parallels the histologic subtype. Most common appearance is a papule or nodule with telangiectasias, which may be eroded or ulcerated.

Generally, men are known to be affected twice as often as women. This could be due to increased work-related exposure to the sun, though these are changing due to the significant changes in lifestyle. The objective of the study is to analyse the different histopathological patterns of Basal Cell Carcinoma (BCC) in 30 consecutive cases of basal cell carcinoma. 


\section{MATERIALS AND METHODS}

This study is a descriptive study of 30 cases of basal cell carcinoma received from January 2016 to December 2017, in the Department of Pathology, Maharajah's Institute of Medical Sciences, Nellimarla, Vizianagaram, situated in Andhra Pradesh, South India. Patients of all ages attending skin outpatient department with suspected lesions were screened for basal cell carcinoma after taking an informed written consent. Patients with histopathologically confirmed basal cell carcinoma were enrolled in the study. A total of 30 cases were studied in the duration of 2 years. A detailed history along with examination and all investigations like laboratory and radiological investigations were conducted. A preoperative photograph was taken. After that surgery (incisional biopsy/ excisional biopsy) was planned.

All the details of specimens received in the pathology department namely identification, history and clinical details were noted. After gross examination findings were recorded and sections from representative areas were taken and subjected to tissue processing by routine histopathological techniques. The excised specimen were fixed in $10 \%$ formalin solution and routinely processed by using automated tissue processor, embedded sections were cut and stained using Haematoxylin and eosin. Special stains were done wherever required.

\section{RESULTS}

A total of 30 cases were included in the study, out of which 14 (46.67\%) were males and 16 (53.33\%) were females with male-to-female ratio of $1: 1.14$. The mean age of the sample patients was 60 years. The mean age amongst male and female was almost the same.

\begin{tabular}{|c|c|c|}
\hline Sex & Number of Cases & Percentage (\%) \\
\hline Male & 14 & 46.67 \\
\hline Female & 16 & 53.33 \\
\hline Total & $\mathbf{3 0}$ & $\mathbf{1 0 0}$ \\
\hline \multicolumn{2}{|c|}{ Table 1. Shows Sex Wise distribution of Basal Cell } \\
Carcinoma \\
\hline
\end{tabular}

\begin{tabular}{|c|c|c|}
\hline Site & Number of Cases & Percentage (\%) \\
\hline Head and Neck & 27 & 90 \\
\hline Trunk & 2 & 6.67 \\
\hline Limb & 1 & 3.33 \\
\hline Total & $\mathbf{3 0}$ & $\mathbf{1 0 0}$ \\
\hline Table 2. Shows Site Wise distribution of Basal Cell \\
Carcinoma \\
\hline
\end{tabular}

In the head and neck, most common site were eyelids and mostly lower eyelids.

\begin{tabular}{|c|c|c|}
\hline Histological Pattern & Number of Cases & Percentage (\%) \\
\hline Solid (Nodular) & 17 & 56.67 \\
\hline Pigmented & 5 & 16.67 \\
\hline $\begin{array}{c}\text { Keratotic } \\
\text { (Basosquamous) }\end{array}$ & 3 & 10 \\
\hline Adenoid & 2 & 6.67 \\
\hline Cystic & 2 & 6.67 \\
\hline Infiltrating & 1 & 3.33 \\
\hline Total & $\mathbf{3 0}$ & $\mathbf{1 0 0}$ \\
\hline Table 3. Shows Histological presentation of Basal Cell \\
Carcinoma \\
\hline
\end{tabular}

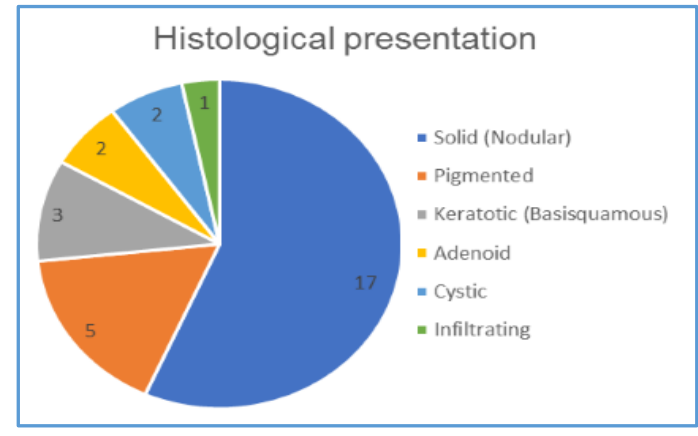

On histological examination the commonest type was solid or nodular with peripheral palisading (56.67\%), the second commonest was pigmented (16.67\%) followed by keratotic (Basosquamous) type (10\%) and adenoid (6.67\%). Cystic type and infiltrating were the least common. Among all the 30 cases, one case was Gorlin-Goltz syndrome.

\section{Histology of Basal Cell Carcinoma}

The most important key feature of basal cell carcinoma at low power magnification are that the basaloid epithelial cells of the tumour arising from the epidermis. This basaloid epithelium forms palisading pattern with clefts forming in between them.

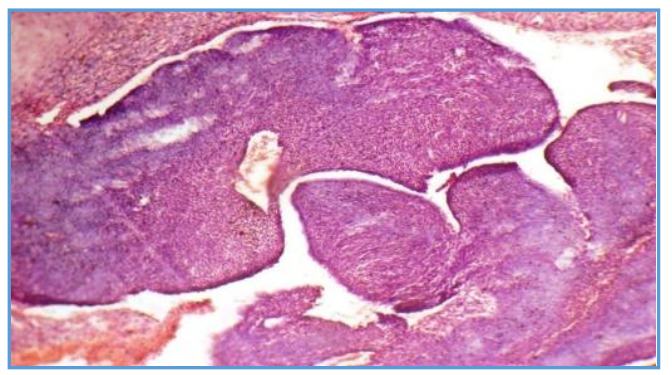

Image 1. Photomicrograph of Basal Cell Carcinoma $H$ and $E$ (100x): Basaloid Cells in Nests separated from Stroma by Artefactual Clefts

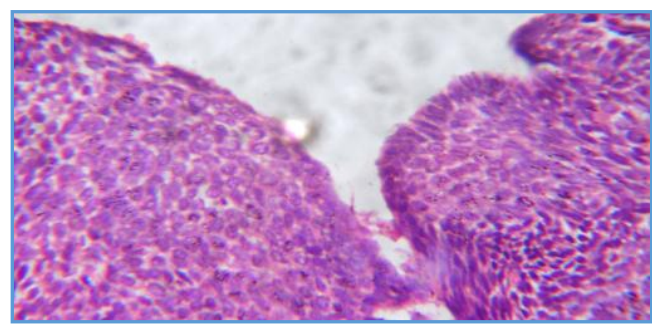

Image 2. H and E (400x): Basaloid Cells with Peripheral Palisading

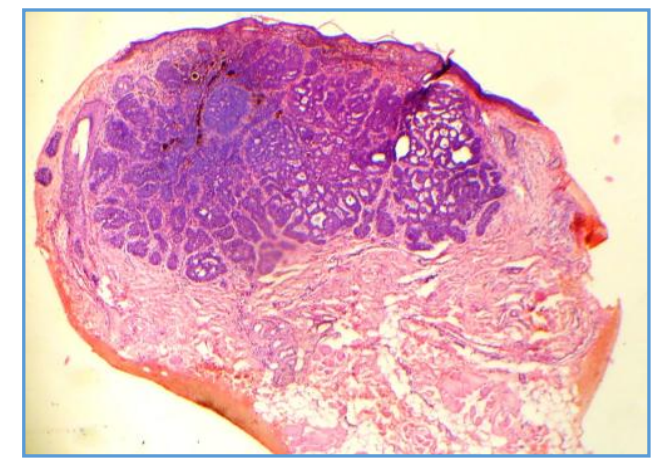

Image 3. Photomicrograph of Pigmented Variant of Basal Cell Carcinoma 


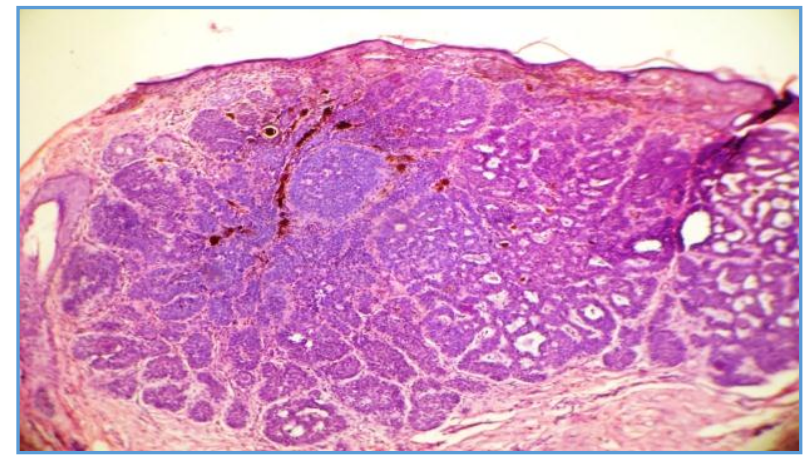

Image 4. H and E (100x): Pigmented Adenoid Basal Cell Carcinoma

\section{Variants of Basal Cell Carcinoma Superficial BCC}

This variant shows nests of atypical basaloid cells as buds from the basal layer of epidermis.

\section{Nodular BCC}

Tumour nodules extending into the subcutaneous tissues.

\section{Pigmented BCC}

Focal deposits of pigment that is melanin in the tumour is seen.

\section{Micronodular BCC}

The tumour is comprised of nodular architecture with multiple small nests. This variant also exhibit extensive infiltration into the surrounding tissue. This variant also has poor prognosis and increased risk of local recurrence.

\section{Infiltrating BCC}

This variant is aggressive with tumour showing extensive infiltrating strands and cords of atypical basaloid cells.

\section{Metatypical BCC}

It is a rare subtype. Peripheral palisading and clefting is not seen in this type.

\section{Sclerosing BCC}

Densely fibrotic stroma in between which the atypical basaloid epithelium is seen.

\section{Infundibulocystic BCC}

This type shows small cysts with cornified material with differentiation towards the infundibulum.

\section{Basosquamous Carcinoma}

The tumour shows large, pale squamoid cells, which lack keratinisation.

\section{Sebaceous Differentiation}

The tumour tissue shows focal areas where the cells show sebaceous differentiation.

\section{DISCUSSION}

Basal cell carcinoma is the most frequently diagnosed skin cancer all over the world. Most common sites affected are the sun exposed hair bearing areas of face and hands, in some cases they may appear in limited or no sun exposed areas.
Basal cell carcinoma around the eye or periocular region is the most common malignancy in humans in the region. The age group in which the malignancy more commonly involves is the older population and most commonly sex involved is the male population.5,6 It has an increased association with increased exposure to sun, dry climate, dusty and hot weather and fair complexion.7 People who are more involved in agricultural occupational background seem to have increased risk. In other countries like United States and the United Kingdom, the most common malignant eyelid tumour reported as per literature is basal cell carcinoma which occurs most frequently on the lower eyelid and medial canthus in elderly patients. ${ }^{8}$

Basal cell carcinoma happens to occur most commonly in adults and it occurs very rarely in children who do not have any predisposing factors or disease. Basal cell carcinoma is also the most common skin malignancy in non-Asian countries and it accounts for $85-95 \%$ among all the malignant epithelial tumours of the eyelid. The lower eyelid and inner canthus are most commonly affected. One of the most important risk factor is prolonged exposure to ultraviolet light. On a whole, the most common clinical presentation of basal cell carcinoma appears as a solitary lesion near the eye (Rodent ulcer), ${ }^{9}$ which is also known as Nevoid Basal Cell Carcinoma (NBCC) Syndrome that is a rare autosomal dominant disorder. This syndrome is an autosomal dominant with strong penetrance and extremely variable expressivity. It was first reported in the year 1894 by Jarish and White. Later Robert J Gorlin and Robort W Goltz described the distinct syndrome, consisting of multiple naevoid BCCs, jaw cysts and bifid ribs. ${ }^{10}$

The frequency of the syndrome varies from country to country. On an average, the incidence of Gorlin-Goltz syndrome is very less and has been reported to be 1 in 50,000 to 150,000 in general population. According to the review of literature, it reveals that only about eight cases of this syndrome are reported from all over India. ${ }^{11}$ It is caused by mutations in the patched tumour suppressor gene (PTCH gene), a human homologue of the Drosophila gene mapped to chromosome 9q21-23. The underlying basis for Gorlin-Goltz syndrome is an abnormality in the Hedgehog $(\mathrm{Hh})$ signalling pathway. The role of this pathway in embryogenesis is well known.

The differential diagnosis of basal cell carcinoma is trichoepithelioma, sebaceoma and microcystic adnexal carcinoma.

In trichoepithelioma the epithelium demonstrates intimate integration with surrounding stroma which can be cellular or fibromyxoid, in contrast basal cell carcinoma typically shows clefting reaction between epithelial cells and surrounding epithelium and stroma.

Immunohistochemistry is not useful but numerous stains are given in the literature which include Bcl-2, Ber-Ep4 and CD 34. Bcl-2 is diffusely positive in basal cell carcinoma, while in trichoepithelioma only highlighting layer is the basal layer.

Sebaceoma usually shows more lobulated architecture, lacking palisading and clefting. Immunostaining is helpful to differentiate as sebaceoma is rarely positive for Ber-EP4, while typically EMA is positive.

With microcystic adnexal carcinoma it is difficult to differentiate from infiltrating basal cell carcinoma and desmoplastic trichoepithelioma. The points which are in 


\section{Jemds.com}

favour of microcystic adnexal carcinoma are those being the deep invasion of the tumour into the surrounding tissue stroma, extensive perineural invasion and glandular differentiation (Ductal differentiation). Immunohistochemical studies like CK 20 are very useful. CK 20 stain is negative in microcystic adnexal carcinoma, while the isolated native Merkel cells show CK 20 positive stain in desmoplastic trichoepithelioma.

The adequate and standard treatment of choice is surgical resection with adequate margins of normal tissue. Now-adays clinicians use Mohs' micrographic surgery to achieve margin clearance in basal cell carcinoma. ${ }^{12}$

\section{CONCLUSION}

High incidence of hyperpigmentation in the lesional skin of basal cell carcinoma is the most characteristic feature found in patients of basal cell carcinoma.

\section{REFERENCES}

[1] Appel T, Bierhoff E, Appel K, et al. Predictive variables for the biological behaviour of basal cell carcinoma of the face: relevance of morphometry of the nuclei. British Journal of Oral and Maxillofacial Surgery 2003;41(3):147-50.

[2] Kirkham N. Tumours and cysts of epidermis. In: Lever's histopathology of skin. 9th edn. Philadelphia: Lippincott Raven 2005: p. 805-66.

[3] Birt B, Cowling I, Coyne S. UVR reflections at the surface of the eye. J photochem Photobiol B. Biology 2004;77(1-3):71-77.

\section{Original Research Article}

[4] Tilli CM, Van Steensel MA, Krekels GA, et al. Molecular aetiology and pathogenesis of basal cell carcinoma. British Journal of Dermatology 2005;152(6):1108-24.

[5] Birt B, Cowling I, Coyne S, et al. The effect of the eye's surface topography on the total irradiance of ultraviolet radiation on the inner canthus. J Photochem Photobiol B 2007;87(1):27-36.

[6] Ostergaard J, Boberg-Ans J, Prause JU, et al. Primary basal cell carcinoma of the caruncle with seeding to the conjunctiva. Eye Pathology Institute, University of Copenhagen, Frederik V's Vej i11. 2100. Graefes Arch Clin Exp Ophthalmol 2005;243(6):615-8.

[7] Mencía-Gutiérrez E, Gutiérrez-Díaz E, Pérez-Martín ME. Lacrimal caruncle primary basal cell carcinoma: case report and review. J Cutan Pathol 2005;32(7):502-5.

[8] Gupta Y, Gahine R, Hussain N, et al. Clinicopathological spectrum of ophthalmic lesions: an experience in tertiary care hospital of central India. J Clin Diagn Res 2017;11(1):EC09-EC13.

[9] Pe"er J. Pathology of eyelid tumors. Indian J Ophthalmol 2016;64(3):177-90.

[10] Sunil MK, Kumar R, Guru EN, et al. Gorlin-Goltz syndrome. J Indian Acad Oral Med Radiol 2010;22:1826.

[11] Jawa DS, Sircar K, Somani R, et al. Gorlin Goltz syndrome: a case report. J Oral Maxillofac Pathol 2009;13(2):89-92.

[12] Janjua OS, Qureshi SM. Basal cell carcinoma of the head and neck region: an analysis of 171 cases. Article ID 943472, Journal of Skin Cancer 2012;2012: p. 4. 